\title{
NORMAS REVISTA FAZ CIÊNCIA
}

\section{INSTRUÇÕES GERAIS}

- As propostas submetidas, pelo (s) autor (es), à publicação na Revista Faz Ciência devem respeitar as normas estabelecidas pela Revista.

- A Revista Faz Ciência é um periódico interdisciplinar, de caráter científico, que publica artigos inéditos, de circulação restrita, resenhas, documentos, que abrangem as diversas áreas das ciências humanas, sociais aplicadas e saúde.

- A Revista recebe artigos em demanda contínua ou sob a forma de núcleos temáticos ou dossiê.

- A Revista Faz Ciência publica artigos nos idiomas Português, Inglês e Espanhol.

- Os textos deverão ser enviados à Revista exclusivamente pelo sistema Online disponível no endereço: http://e-revista.unioeste.br/index.php/fazciencia Os autores devem seguir os passos do processo de submissão de artigos.

- Os originais não serão devolvidos aos autores.

- Os artigos devem ter no máximo três autores.

- O envio dos textos implica a cessão de direitos autorais e de publicação à Revista Faz Ciência.

- Os trabalhos científicos publicados são de inteira responsabilidade do(s) autor(es).

- Não haverá custo para o autor para publicação na Revista Faz Ciência.

- O (s) autor (es) que submeterem artigos à Revista Faz Ciência devem seguir as instruções gerais (item 1) e as normas para publicação (item 2), assim como tomar ciência das informações disponibilizadas na página da Revista. Os trabalhos que não estiverem em conformidade com as normas estabelecidas nesta instrução não serão aceitos.

\section{NORMAS PARA PUBLICAÇÃO}

- A composição dos trabalhos, obrigatoriamente, deverá obedecer às seguintes orientações:

Editor de textos: Microsoft Word (7.0 ou posterior);

Número de laudas: 15 (quinze) a 25 (vinte);

Tamanho do papel: A4 $(21 \times 29,7 \mathrm{~cm})$;

Margens: - superior: 2,0 cm; - inferior: 2,0 cm; - esquerda: 2,5 cm, - direita: 2,0 cm;

Espaço entre linhas: $1,5 \mathrm{~cm}$;

Recuo de parágrafo: $1,25 \mathrm{~cm}$; 
Alinhamento do texto: justificado;

Tipo de fonte do texto: Times New Roman (tamanho 12);

Numeração de página: algarismos arábicos.

OBS - É de responsabilidade dos autores a revisão gramatical e ortográfica.

- Os artgos devem ser normatizados da seguinte forma:

TÍTULO: deve anteceder ao resumo de cada idioma, centralizado, letra maiúscula e fonte tamanho 14 .

IDENTIFICAÇÃO DOS AUTORES: Conforme as indicações do sistema;

NOTAS DE RODAPÉ: somente explicativas. Recomenda-se evitar a utilização excessiva de notas;

RESUMO/ABSTRACT/RESUMEM: fonte em itálico tamanho 10, espaço simples, alinhamento justificado sem parágrafo, no máximo de 10 linhas. Texto em português, obrigatoriamente, resumos em português e inglês. Texto em inglês, obrigatoriamente, resumos em inglês e português. Texto em espanhol, obrigatoriamente, resumo em espanhol e português. Recomenda-se que os textos estejam acompanhados dos resumos das três línguas.

PALAVRAS-CHAVE/KEY-WORDS/PALABRAS CLAVE: máximo cinco;

TEXTO: conforme as normas da ABNT, sem numeração nos subtítulos. A diagramação obedecerá às normas da Revista Faz Ciência. As citações devem ser feitas no corpo do texto: (Sobrenome do autor, data) ou (Sobrenome do autor, data, página). Ex: (SAQUET, 2000) ou (SAQUET, 2000, p. 31). Caso o nome do autor esteja sendo mencionado no texto, indicar somente a data. Ex: "Desta forma, Santos (1997), mostra elementos da...".

CITAÇÕES: até três linhas no corpo do texto, acima de três linhas recuadas com margem de $4 \mathrm{~cm}$, espaçamento simples, fonte 11, com um espaço antes e outro depois da citação.

REFERÊNCIAS: conforme a ABNT. Bibliografia: deve constar no final do trabalho científico e em ordem alfabética. a) Livros: SOBRENOME, Nome. Título da obra. Local de publicação: Editora, ano. Ex: CORRÊA, Roberto. A rede urbana. São Paulo: Ática, 1989.; b) Capítulo de livro: SOBRENOME, Nome. Título do capítulo. In: SOBRENOME, Nome (Org). Título do livro. Local de publicação: Editora, ano. Página inicial-final. Ex: IANNI, Octávio. Dilemas da integração regional. In: SOUZA, Álvaro (Org). Paisagem território região: em busca da identidade. Cascavel: EDUNIOESTE, 2000. p.133-136.; c) Artigo em periódico: SOBRENOME, Nome. Título do artigo. Título do periódico, local de publicação, volume, número, página inicial-final, mês(es). Ano. Ex: MACHADO, Lucy. Cognição ambiental, processo educativo e sociedades sustentáveis. Faz Ciência, Francisco Beltrão, vol. 5, n.1, p.131- 
146, dezembro, 2003.; d) Artigos em meio eletrônico: acrescentar Disponível em: endereço página da internet. Acesso em dia/mês/ano. e) Dissertações e teses: SOBRENOME, Nome. Título da tese (dissertação). Local: Instituição em que foi defendida, ano. Número de páginas. (Categoria, grau e área de concentração). Ex.: RIBAS, Alexandre. Gestão político-territorial dos assentamentos, no Pontal do Paranapanema (SP): uma leitura a partir da COCAMP. Presidente Prudente: FCT/UNESP, 2002. 224p. (Dissertação, mestrado em Geografia).

\section{TRÂMITE DE ANÁLISE DAS PROPOSTAS DE PUBLICAÇÃO}

3.1 RECEPÇÃO: pelo sistema da Revista disponível no endereço: $\underline{\text { http://e- }}$ revista.unioeste.br/index.php/fazciencia Os artigos que não atenderem as normas da Revista não serão encaminhados para a etapa de avaliação pelos pareceristas.

3.2 PARECERISTAS: Os artigos (sem identificação dos autores) serão enviados, para apreciação, a dois pareceristas, preferencialmente doutores e de outras instituições, garantindo-lhes o anonimato. Esses são selecionados pelo Conselho Editorial. O parecer pode ser favorável à publicação, favorável à publicação com alterações ou desfavorável. Acompanha o trabalho um formulário com critérios para avaliação e orientação aos consultores.

3.3 ENVIO DO PARECER À REVISTA: Assim que os pareceristas efetuarem a devolução das cópias devidamente apreciadas, o Editor compila os comentários:

a) Caso os dois pareceristas aprovem o trabalho sem alterações, esse é encaminhado para a etapa de edição.

b) Caso os pareceristas solicitem alterações, o artigo retorna ao(s) autor(es) para correções.

c) E, caso os pareceres sejam desfavoráveis, serão enviadas cópias dos pareceres ao(s) autor(es) e encerrado o processo.

Para a aprovação do trabalho é necessário que ambos os pareceristas sejam favoráveis (com e, ou sem alterações). Caso um deles seja desfavorável e ou outro favorável (com ou sem alterações), o artigo será enviado a um terceiro parecerista.

3.4 RETORNO À REVISTA: No caso do item “3.3b”, após as correções pelos autores, o trabalho retorna à Revista.

3.5 PUBLICAÇÃO: De posse dos artigos, processa-se a diagramação do número da Revista para publicação. 


\title{
MAIS INFORMAÇÕES:
}

\author{
U N I O E S T E
}

Universidade Estadual do Oeste do Paraná - Campus de Francisco Beltrão Revista Faz Ciência (André Paulo Castanha - Editor Científico)

Rua Maringá, no 1200 - Bairro Vila Nova.

Francisco Beltrão - PR - CEP: 85605-010

Endereço eletrônico: revista.fazciencia@unioeste.br

Telefones: (46) 3520- 4848 ou (46) 3520-4848 